\title{
Cattle Diet and Daily Gains on a Mountain Riparian Meadow in Northeastern Oregon
}

\author{
J.L. HOLECHEK, M. VAVRA, AND J. SKOVLIN
}

\begin{abstract}
Cattle weight gains, diet botanical composition, and diet quality on a riparian meadow range in the Blue Mountains of eastern Oregon were evaluated in the late summer and fall in 1976, 1977, and 1978. Pregnant yearling heifers were used to evaluate livestock performance. Esophageally fistulated cows were used to evaluate diet botanical composition and diet quality. Cattle diets showed little difference in botanical composition between periods or years. Grasses comprised an average of $80 \%$ of the diet during the 3 year period. Kentucky bluegrass (Poa pratensis) was the most important grass in cattle diets and had the highest percent cover on the study pastures. Cattle diet quality showed little change within or between years. Crude protein concentrations appeared adequate for cattle to gain $.5 \mathrm{~kg}$ per day. However, estimated digestible energy concentrations averaged only $80 \%$ of that recommended by the NRC. Daily gains were erratic hetween and within years averaging .41 kg for the 3 years. Average daily gains on the meadow were better than or equal to those reported in other studies for upland and upland and meadow pastures at the Starkey Range for the same periods. Separate fencing and deferred grazing of mountain meadows could improve cattle performance and aid ranchers in gathering cattle at the end of the grazing season. In addition deferred grazing should result in pasture improvement and provide better habitat for nesting birds. The primary disadvantage of deferred use of meadows would be the cost of fencing.
\end{abstract}

Riparian mountain meadows are a highly productive and important forage resource in many parts of the western United States. These areas are of particular value to the public from the standpoint of water and recreation. They also provide important fish and wildlife habitat. A rapidly increasing demand for the previously mentioned products dictates that riparian mountain meadows must be managed more intensively in the future than in the past.

Under season long grazing riparian mountain meadows often receive excessive use even under light or moderate stocking rates because they are situated in low, flat areas with abundant forage and water (Roath et al. 1982). One way of eliminating this problem is separate fencing of riparian mountain meadows from surrounding uplands. A recent study by Kauffman et al. (1982) shows that delayed grazing of riparian meadows may reduce or eliminate adverse impacts of grazing on nongame wildlife. Restriction of livestock to upland areas in the early part of the grazing season would allow deferment of riparian mountain meadows and should rcsult in subsequent improvement in their condition. This could also aid in gathering livestock at the end of the grazing season as livestock would be concentrated on accessible terrain. The effect of deferred grazing of riparian mountain meadows on cattle diet and Authors are, respectively. graduate research assistant; associate professor, range-
land resources, OSU, Eastern Oregon Agricult ural Research Center, Union; professor and project leader, USDA Range and Wildlife Habitat Laboratory, La Grande. J.L. Holechek is currently assistant professor of range ecology, Department of Animal and Range Sciences, New Mexico State University, Las Cruces $\mathbf{8 8 0 0 3 .}$

This report is Oregon State Agricultural Experiment Station Technical Paper Number 6313. This research was jointly funded by the Eastern Oregon Agricultural Research Center, Oregon State University and the Pacific Northwest Forest and Range Experiment Station, United States Forest Service, USDA, and was part of the PNWFRES Project 1701 entitled, "The influence of cattle grazing methods and big game on riparian vegetation, aquatic habitat and fish populations." performance has not been reported. The objectives of our study were to determine the botanical composition and nut ritive value of the diet and cattle weight gains on a riparian mountain meadow in the Blue Mountains of northeastern Oregon.

\section{Experimental Site and Procedures}

The study site was located on the Starkey Experimental Range and Forest $48 \mathrm{~km}$ southwest of La Grande, Ore. Moderately deep canyon drainages separating broad rolling uplands characterize the topography of the Starkey Range. Elevations range from 1,080 to $1,525 \mathrm{~m}$. A description of the soils of the study area is given by Strickler (1966). The average annual precipitation is approximately $53 \mathrm{~cm}$ and comes as snow and rainfall in the winter and spring. There is sufficient summer rainfall to result in fall regrowth in approximately one year out of two. Precipitation at Starkey in 1976, 1977, and 1978 is presented in Table 1.

Two 10-ha pastures having the same grazing history were established in 1975. Vegetation composition and structure of the pastures was nearly identical. Vegetation of the pastures is quite diverse and typical of riparian meadows in the Blue Mountains (Ganskopp 1978). As the result of disturbance most of the original vegetation has been severely altered. Many of the riparian meadows have been reseeded to introduced pasture grasses one or more times. Kentucky bluegrass (Poa pratensis) presently dominates the understory of many of the meadows. Under pristine conditions tufted hairgrass (Deschampsia caespitosa) was the dominant grass. Dominant forbs on the meadows include cinquefoil (Potentilla sp.) and western yarrow (Achillea millefolium lanulosa). Both of these forbs are increasers and cinquefoil is particularly unpalatable to cattle (Pickford and Reid 1948). A variety of shrubs is found in the meadows although common snowberry (Symphoricarpos albus) and black hawthorn (Crataegus douglasii) predominate. Common snowberry is an important forage species for cattle in the Blue Mountains but black hawthorn receives little or no use. Most of the species on the study area were perennials; thus, only slight variations were found in species composition among years. Cover data were pooled across pastures because the vegetation composition of the two pastures was similar (Table 2).

Table 1. Precipitation in $\mathrm{cm}$ at the Starkey Experimental Range and Forest.

\begin{tabular}{lcccc}
\hline \hline Month & 25 year $X$ & 1976 & 1977 & 1978 \\
\hline January & 6.48 & 6.86 & 1.02 & 5.08 \\
February & 4.27 & 2.29 & 2.54 & 4.06 \\
March & 4.57 & 2.54 & 2.11 & 3.56 \\
April & 4.42 & 5.08 & 2.79 & 6.68 \\
May & 5.44 & 4.39 & 4.80 & 4.01 \\
June & 4.72 & 3.71 & 1.83 & 3.12 \\
July & 1.57 & .05 & .13 & 2.54 \\
August & 2.01 & 6.86 & 7.42 & 3.43 \\
September & 2.72 & 3.71 & 9.42 & 4.11 \\
October & 4.52 & 2.67 & 3.76 & 7.11 \\
November & 5.66 & 4.06 & 7.75 & 4.06 \\
December & 6.68 & 0.00 & 9.40 & 3.20 \\
$\quad$ Total & 53.06 & 42.22 & 52.97 & 50.96 \\
\hline
\end{tabular}


Table 2. Percent cover pooled by pastures of the primary forage species and their contribution by percent weight to cattle diets pooled by grazing periods and years. Pasture cover data are from Ganskopp (1978).

\begin{tabular}{lcc}
\hline \hline Species & $\begin{array}{c}\text { Percent } \\
\text { cover }\end{array}$ & $\begin{array}{c}\text { Percent } \\
\text { in diet }\end{array}$ \\
\hline Kentucky bluegrass (Poa pratensis) & 21 & 12 \\
Sheep fescue (Festuca ovina) & 6 & 8 \\
Smatl fruited bulrush (Scirpus microcarpus) & 5 & 8 \\
Spike bentgrass (Agrostis exarata) & 2 & 8 \\
Timothy (Phleum pratense) & 4 & 4 \\
Meadow foxtail (Alopecurus pratensis) & 4 & 5 \\
Mountain brome (Bromus carinatus) & 2 & 3 \\
Idaho fescue (Festuca idahoensis) & 4 & 8 \\
Sedge (Carex sp.) & 6 & 5 \\
Rush (Juncus sp.) & 5 & 3 \\
Other grasses and grasslikes & 8 & 16 \\
$\quad$ Total grasses and grasslikes & 67 & 80 \\
Western yarrow (Achillea millefolium lanulosa) & 2 & 2 \\
Clover (Trifolium sp.) & 1 & 2 \\
Cinquefoil (Potentilla sp.) & 6 & 0 \\
Other forbs & 4 & 8 \\
$\quad$ Total forbs & 13 & 12 \\
Common snowberry (Symphoricarpos albus) & 8 & 6 \\
Black hawthorn (Crataegus sp.) & 5 & 0 \\
Willow (Salix sp.) & $<1$ & 0 \\
Saskatoon serviceberry (Amelanchier alnifolia) & 1 & T \\
Wax currant (Ribes cereum) & 1 & T \\
Baldhip rose (Rosa gymnocarpa) & 1 & T \\
Other shrubs & 3 & 1 \\
Total shrubs & 20 & 8 \\
\hline
\end{tabular}

The two study pastures were adjacent to each other and enclosed with a 4-strand barb wire fence. Meadow Creek bisected each pasture. Cattle were grazed on the pastures from August 16 to October 10 in 1976, 1977, and 1978. The grazing season was divided into two 28-day periods which extended from August 16 to September 12 (late summer) and September 13 to October 10 (fall). The cattle were grazed the first 28 days on one pasture and then rotated to the other. Under this strategy each pasture was grazed in the late summer every other year.

Three esophageally fistulated cows were used to collect diet samples in all 3 years of study. In addition, 11 head of pregnant yearling heifers were grazed on the pastures. A moderate stocking rate was assigned after criteria developed by Skovlin et al. (1976).
The performance of the 11 heifers on the pastures was evaluated by weighing without shrink at the onset of grazing and the end of each 28-day grazing period.

Every other week 2 collections were made with the fistulated animals. Fistulated cows were grazed continuously on the pasture under study in all periods. Two samples were collected from each cow on the same week on a biweekly basis. The collection procedure involved grazing the fistulated cows to various parts of the pasture and allowing them to graze freely until at least $1 \mathrm{~kg}$ of grazed forage was acquired. Esophageal fistula samples were dried in a forced air over at $40^{\circ} \mathrm{C}$ for 7 days and then ground through a 1-mm screen. Crude protein was determined by the Kjedahl technique to include nitrates. In vitro organic matter digestibility (IVOMD) was determined by a modification of the Tilley and Terry (1963) technique (Vavra et al. 1973). Acid detergent fiber (ADF) and lignin were determined by the permanga nate method of Van Soest and Wine (1968).

Digestible energy (DE) values were predicted from IVOMD using the following regression equation developed by Rittenhouse et al. (1971): Mcal DE/kg DM =.039 (OMD) - 10 .

The microhistological technique of Sparks and Malechek (1968) was used in botanical analysis of diet samples. Twenty microscope fields on each of 3 slides were examined at $100 \times$ for each sample.

A completely randomized design and a standard $F$-test were used for all statistical comparisons. Covariance analysis was used to determine the relationship among initial weights at the beginning of each period and average daily gains.

\section{Results and Discussion}

Cattle diets on the meadow showed little difference between years or periods (Table 3). During the 3 yea rs of study, 24 grasses, 9 forbs, and 5 shrubs were found in cattle diet samples. When samples were pooled across years and periods, Kentucky bluegrass was the most important species in the diet (Table 2). During each year there was incrcased dietary consumption of grasses and decreased consumption for forbs and shrubs in the fall compared to the late summer. Studies on upland ranges at Starkey have shown a decrease in forb consumption with seasonal advance (Pickford and Reid 1948, Holechek et al. 1982a,b). Some grass regrowth was available in the fall in all 3 years of study, which may further explain the increase in grass consumption. Common snowberry was the only shrub of importance in cattle diets. Other studies on upland ranges at Starkey have shown this shrub is heavily used by cattle particularly during drought (Holechek et al. 1982a,b).

Table 3. The percent by weight of important species found in cattle diets in 1976, 1977, and 1978.

\begin{tabular}{|c|c|c|c|c|c|c|}
\hline \multirow[b]{2}{*}{ Species } & \multicolumn{2}{|c|}{1976} & \multicolumn{2}{|c|}{1977} & \multirow[b]{2}{*}{ Late summer } & \multirow[b]{2}{*}{ Fal! } \\
\hline & Late summer & Fall & Late summer & Fall & & \\
\hline Kentucky bluegrass & 12 & 15 & 10 & 8 & 12 & 15 \\
\hline Sheep fescue & 7 & 6 & $7^{a}$ & $13^{b}$ & 7 & 6 \\
\hline Small fruited bulrush & 10 & 6 & 9 & 6 & 8 & 6 \\
\hline Spike bentgrass & 9 & 4 & $6^{a}$ & $13^{b}$ & 9 & 3 \\
\hline Timothy & 5 & 5 & 2 & 3 & 5 & 5 \\
\hline Meadow foxtail & 4 & 7 & 1 & 3 & 5 & 7 \\
\hline Mountain brome & $\mathrm{T}$ & 4 & 2 & 3 & $\mathbf{T}$ & 4 \\
\hline Idaho fescue & $6^{b}$ & $12^{a}$ & 4 & 7 & 6 & 11 \\
\hline Sedge & 3 & 1 & 7 & 4 & 4 & 2 \\
\hline Rush & 2 & 3 & 5 & 2 & $T$ & 1 \\
\hline Other grass and grasslikes & 17 & 23 & 19 & 23 & 17 & 26 \\
\hline Total grasses and grasslikes & $75^{\mathrm{a}}$ & $86^{b}$ & $72^{\mathrm{a}}$ & $85^{b}$ & $72^{a}$ & $86^{b}$ \\
\hline Western yarrow & 2 & 4 & $\mathbf{T}$ & $\mathbf{T}$ & $\mathrm{T}$ & 4 \\
\hline Clover & 4 & 1 & 1 & $\mathrm{~T}$ & 2 & 2 \\
\hline Other forbs & 12 & 7 & 12 & 9 & 16 & 6 \\
\hline Total forbs & $18^{a}$ & $12^{b}$ & 14 & 10 & $18^{a}$ & $12^{\mathrm{b}}$ \\
\hline Snowberry & 3 & $\mathbf{T}$ & 13 & $2^{b}$ & 2 & 4 \\
\hline Other shrubs & 4 & 2 & 1 & 3 & 8 & $\mathrm{~T}$ \\
\hline Total shrubs & 7 & 2 & $14^{a}$ & $5^{b}$ & $10^{2}$ & $2^{b}$ \\
\hline
\end{tabular}

\footnotetext{
a.b Means with different superscripts within row and year are significantly different at the .05 level.
}

$\mathrm{T}=$ trace 
Table 4. Average cattle diet chemical composition on an organic matter basis, in vitro organic matter digestibility, estimated digestible energy and average daily gains.

\begin{tabular}{|c|c|c|c|c|c|c|}
\hline \multirow[b]{2}{*}{ Item } & \multicolumn{2}{|c|}{1976} & \multicolumn{2}{|c|}{1977} & \multicolumn{2}{|c|}{1978} \\
\hline & Late summer & Fall & Late summer & Fall & Late summer & Fall \\
\hline $\begin{array}{l}\text { Crude protein }(\%) \\
\text { Acid detergent fiber }(\%) \\
\text { Lignin }(\%) \\
\text { In vitro OM digestibility }(\%)\end{array}$ & $\begin{array}{l}10.9 \\
59.3 \\
15.3 \\
51.6\end{array}$ & $\begin{array}{l}10.7 \\
61.2 \\
16.9 \\
55.4\end{array}$ & $\begin{array}{c}9.1 \\
56.9^{\mathrm{a}} \\
11.8 \\
51.8^{\mathrm{a}}\end{array}$ & $\begin{array}{l}8.8 \\
60.1^{\mathrm{b}} \\
12.1^{\mathrm{b}} \\
44.2^{\mathrm{b}}\end{array}$ & $\begin{array}{c}9.6 \\
57.3 \\
15.4^{a} \\
51.4\end{array}$ & $\begin{array}{c}9.2 \\
59.0 \\
12.2^{\mathrm{b}} \\
50.1\end{array}$ \\
\hline $\begin{array}{l}\text { Estimated digestible energy } \\
(\mathrm{Mcal} / \mathrm{kg})\end{array}$ & 1.9 & 2.1 & $2.0^{\mathrm{a}}$ & $1.6^{b}$ & 1.9 & 1.8 \\
\hline $\begin{array}{l}\text { Average daily gains }(\mathrm{kg} / \text { day) } \\
\text { riparian meadow }\end{array}$ & $+0.99^{\mathrm{a}}$ & $+0.13^{b}$ & $+0.46^{\mathrm{a}}$ & $-0.16^{b}$ & $-0.04^{n}$ & $+0.74^{b}$ \\
\hline $\begin{array}{l}\text { Average daily gains (kg/day) } \\
\text { seasonlong pasture }\end{array}$ & +0.63 & +0.66 & +0.05 & +0.31 & +0.30 & +0.55 \\
\hline $\begin{array}{l}\text { Average daily gains }(\mathrm{kg} / \mathrm{day}) \\
\text { upland grassland }\end{array}$ & +0.41 & +0.40 & +0.08 & +0.29 & -0.40 & +0.28 \\
\hline $\begin{array}{l}\text { Average daily gains }(\mathrm{kg} / \text { day }) \\
\text { upland forest }{ }^{2}\end{array}$ & +0.51 & +0.38 & +0.72 & +0.33 & -0.37 & +0.46 \\
\hline
\end{tabular}

ab Means within year with different superscripts differ at the .05 level.

Ifrom Holechek (1980)

ifrom Holechek et al. (1981).

There were no consistent differences in cattle diet nutrient components and in vitro organic matter digestibility between late summer and fall (Table 4). Crude protein was lower $(P<.05)$ in cattle diets in 1977 than 1976 or 1977. This is attributed to reduced precipitation in May and June in 1977 compared to 1976 and 1978. Total May and June precipitation values were highly correlated with diet crude protein values for the late summer $(r=1.0)$ and fall $(r=.99)$

Because forage intake was unknown, it was impossible to determine if cattle met their energy and protein requirements. The protein requirements recommended by the NRC (1976) indicate that $350 \mathrm{~kg}$ pregnant yearling heifers require a crude protein concentration of $8.7 \%$ on a dry matter basis for a $.5 \mathrm{~kg}$ gain. This value can be made more comparable to data presented in Table 4 by dividing it by .9 which represents the average organic matter content of many forages. This gives a recommended value of $9.7 \%$ crude protein on an organic matter basis. The data in Table 4 suggest that crude protein concentrations in the diet were not a serious limitation to livestock performance. The NRC (1976) recommended digestible energy concentration for a $350-\mathrm{kg}$ pregnant yearling heifer to gain $.5 \mathrm{~kg}$ per day is $2.6 \mathrm{Mcal} / \mathrm{kg}$ of forage on an organic matter basis. Estimated digestible energy concentrations shown in Table 4 never exceeded $80 \%$ of this requirement. Digestible energy was evidently much more limiting to cattle performance than crude protein.

Cattle weight gains were erratic and there was no consistent difference between the summer and fall when years were compared (Table 4). Holechek (1980), in a separate study at Starkey, reported cattle diet quality and weight gains for season long unrestricted pastures (upland + riparian) near the meadow pastures during the same years (Table 4). Diet quality was slightly higher on the season long pastures compared to the meadow. Average daily gains on the season long pastures were not consistent to those on the meadow. These data show average daily gains on the meadow pastures are superior to those on the season long pasture in the late summer in two years out of three but the reverse was true for the fall period. There was no consistent differences between cattle gains on the meadow and cattle gains on upland forest and grassland ranges at Starkey (Table 4). Vavra and Phillips (1979, 1980) reported increased diet quality when cattle were turned on a riparian meadow in the Wallowa Mountains of Oregon. Daily gain of calves increased $.2 \mathrm{~kg}$ per day while cows that were losing weight on upland range gained weight on the meadow.

From the standpoint of cattle weight gain and diet quality, there is no clearcut advantage or disadvantage to delayed use of riparian meadows in the Blue Mountains. Improved gains resulting from delayed use of riparian meadows appear to be both location and year dependent. Late season use of riparian meadows has benefits from the standpoint reduced livestock gathering problems and

possible improved range condition. From a wildlife standpoint, bird nesting and small mammal reproduction would be completed so cattle effects would be minimal (Kauffman et al. 1982). The primary disadvantage would be the cost of fencing.

\section{Literature Cited}

Ganskopp, D.C. 1978. Plant communities and habitat types of the Meadow Creek Experimental Watershed. M.S. Thesis. Oregon State Univ., Corvallis. $151 \mathrm{p}$.

Holechek, J.L. 1980. The effects of vegetation type and grazing system on the performance, diet and intake of yearling cattle. Ph.D. Thesis. Oregon State Univ., Corvallis. 247 p.

Holechek, J.L., M. Vavra, and J. Skovlin. 1981. Diet quality and performance of cattle on forest and grassland range. J. Anima. Sci. 53:291-298.

Holechek, J.L., M. Vavra, J. Skovlin, and W.C. Krueger. 1982a. Cattle dicts in the Blue Mountains of Oregon: Forests. J. Range Manage. (in press)

Holechek, J.L., M. Vavra, J. Skovlin, and W.C. Krueger. 1982b. Cattle diets in the Blue Mountains of Oregon: Grasslands. J. Range Manage. 35: 109-112.

Kauffman, J.B., W.C. Krueger, and M. Vavra. 1982. Impacts of a late season grazing scheme on nongame wildlife in a Wallowa Mountain riparian ecosystem. Wildlife-Livestock Relationships Symposium:Proceedings 10. Univ. of Idaho, Moscow. p. 208-219.

NRC. 1976. Nutrient Requirements of Domestic Animals, No. 4. Nutrient Requirements of Beef Cattle. Fifth Revised Ed. Nat. Acad. Sci.-Nat. Res. Counc., Washington, D.C.

Pickford, G.D., and E.H. Reid. 1948. Forage utilization on summer cattle ranges in eastern Oregon. USDA Circular. 79627 p.

Rittenhouse, L.R., C.L. Streeter, and D.C. Clanton. 1971. Estimating digestible energy from dry and orga nic matter in diets of grazing cattle. J. Range Manage. 24:73-75.

Roath, L.R., and W.C. Krueger. 1982. Cattle grazing influence on a mountain riparian meadow. J. Range. Manage. 35:100-104.

Skovlin, J.M., R.W. Harris, G.S. Strickler, and G.A. Garrison. 1976. Effects of cattle grazing methods on ponderosa pine bunchgrass range in the Pacific Northwest. USDA, FS Pac. Northwest Forest and Range Exp. Sta. Res. Bull. 1531 .

Sparks, D.R., and J.C. Malechek. 1968. Estimating percentage dry weight in diets using a microscope technique. J. Range Manage. 21:264-265.

Strickler, G.S. 1966. Soil and vegetation on the Starkey Experimental Range and Forest. Soc. of Amer. Foresters Proc. 1965.

Tilley, J.M., and R.A. Terry. 1963. A two-stage technique for the in vitro digestion of forage crops. J. Brit. Grassl. Soc. 18:104-111.

Van Soest, P.J., and R.H. Wine. 1968. Determination of lignin and cellulose in acid detergent fiber with permanganate. J. Ass. of Off. Agr. Chem. 51:780-789.

Vavra, M., R.W. Rice, and R.E. Bement. 1973. Chemical composition of the diet, intake and gain of yearling cattle under different grazing intensities. J. Anim. Sci. 36:411-414.

Vavra, M., and R.L. Phillips. 1979. Diet quality and cattle performance on forested rangelands in northestern Oregon. Proc. West. Sec. Amer. Soc. Anim. Sci. 30:170-173.

Vavra, M., and R.L. Phillips. 1980. Drought effects on cattle performance, diet and intake. Proc. West. Sec. Am. Soc. Anim. Sci. 31:157-160. 